\title{
ERRATUM
}

Charlotte B. Sørensen - Anne-Margrethe Krogsdam •

Marie S. Andersen - Karsten Kristiansen - Lars Bolund •

Thomas G. Jensen

\section{Site-specific strand bias in gene correction using single-stranded oligonucleotides}

Published online: 13 May 2005

(C) Springer-Verlag 2005

The online version of the original article can be found at http://dx. doi.org/10.1007/s00109-004-0592-6

C. B. Sørensen $(\bowtie) \cdot$ M. S. Andersen · L. Bolund · T. G. Jensen Department of Human Genetics, University of Aarhus, Wilhelm Meyers Allé Bld. 240,

8000 Aarhus C, Denmark e-mail: cbs@humgen.au.dk

Tel.: $+45-8942-1659$

Fax: $+45-8612-3173$

A.-M. Krogsdam $\cdot$ K. Kristiansen Department of Biochemistry and Molecular Biology, University of Southern Denmark, Odense, Denmark

\section{J Mol Med (2005) 83:39-49}

In the Material and Methods section entitled "Cell culture and transfections" the ssODN concentration should be $0.25 \mu \mathrm{M}$ instead of $0.25 \mathrm{mM}$.

An error occurred in the top panel of Fig. 2. The corrected part of Fig. 2 is given below.

An error occurred in the plotting of data for the top panels of Fig. 4. The corrected versions of Fig. 4A and B are given below.
Fig. 2 ssODN sequences used for correction of the episomal E. coli $\beta$-galactosidase gene. Upper, lower case DNA and $2^{\prime}$ - $O$-methyl uracil residues, respectively. The targeted bases in the target sequence and the corresponding complementary or mismatched bases in the ssODNs are underlined

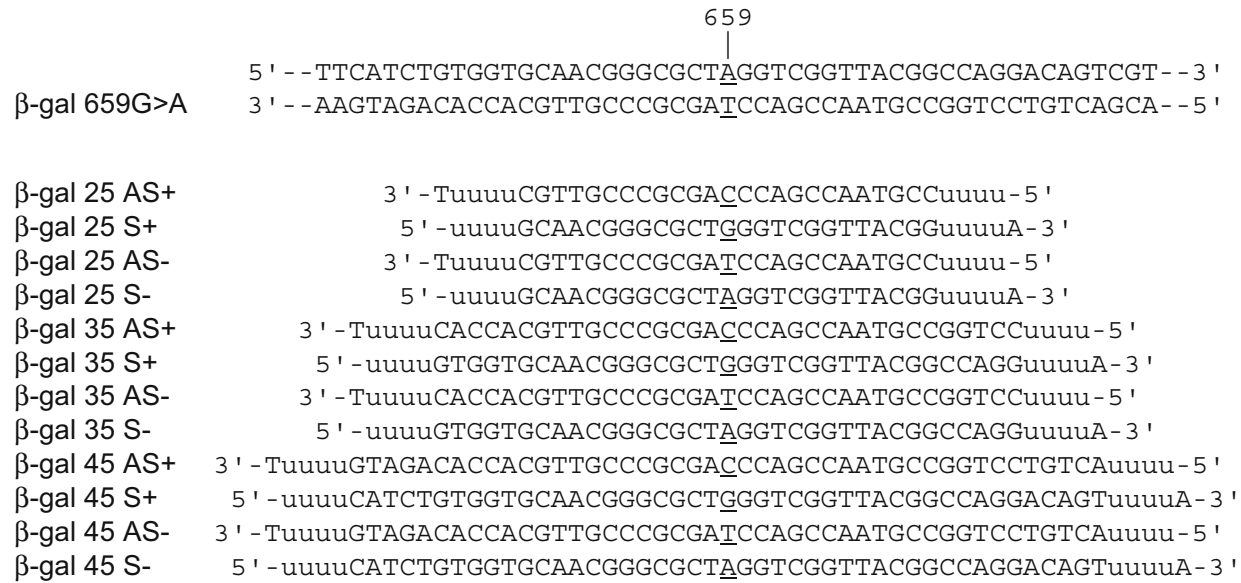

$\beta$-gal $25 \mathrm{AS}+$ $\beta$-gal $25 \mathrm{~S}+$ $\beta$-gal 25 AS$\beta$-gal $25 \mathrm{~S}-$ $\beta$-gal 35 AS+ $\beta$-gal $35 \mathrm{~S}+$ $\beta$-gal 35 AS$\beta$-gal 35 S-

$\beta-$ gal 45 AS+ $\beta-g a l 45 \mathrm{~S}+$ $\beta$-gal 45 AS$\beta$-gal 45 S- 


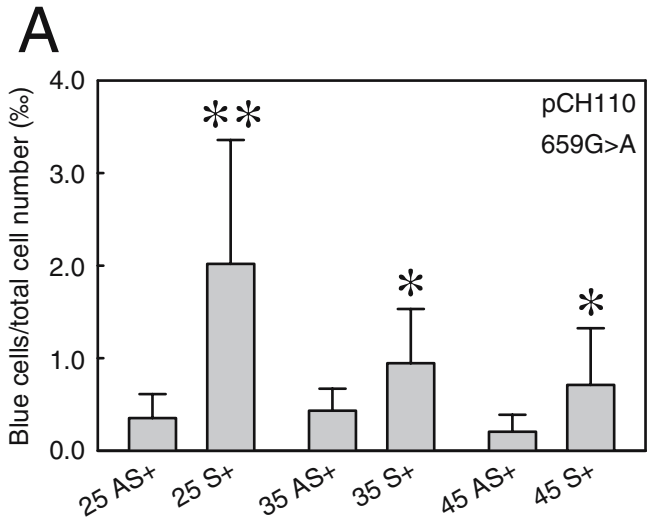

Fig. 4 Correction of the $E$. coli $\beta$-galactosidase $659 \mathrm{G}>\mathrm{A}$ mutation in $\mathrm{CHO}-\mathrm{K} 1$ cells. The correction frequencies were calculated as the number of blue cells divided by the total number of cells. Data are given as mean $+\mathrm{SD}$. Comparison of the correction frequencies obtained by treatment with: A ssODNs $\beta$-gal $25 \mathrm{AS}+, \beta$-gal $25 \mathrm{~S}+$,

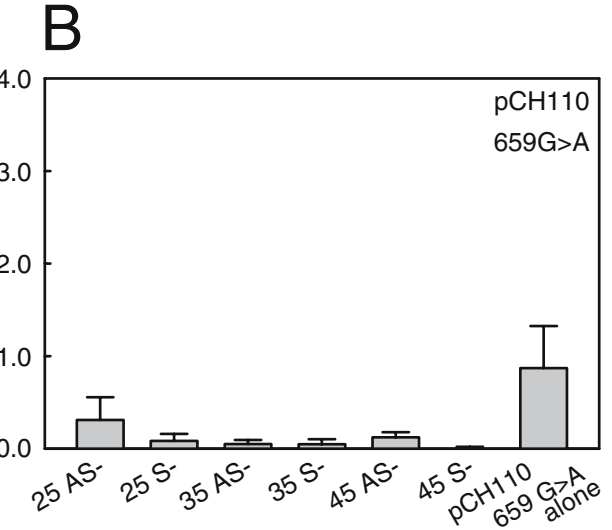

$\beta$-gal $35 \mathrm{AS}+, \beta$-gal $35 \mathrm{~S}+, \beta$-gal $45 \mathrm{AS}+$, and $\beta$-gal $45 \mathrm{~S}+(n=8$ for all samples); B ssODNs $\beta$-gal 25 AS-, $\beta$-gal $25 \mathrm{~S}-$, $\beta$-gal 35 AS-, $\beta$-gal $35 \mathrm{~S}-$, $\beta$-gal $45 \mathrm{AS}-, \beta$-gal $45 \mathrm{~S}^{-}$, and the mutant plasmid pCH110 $659 \mathrm{G}>\mathrm{A}$ alone ( $n=3$ for all samples). $P \leq 0.05$ (see text for details) 